\title{
Bio-hydrogen Production from Beer Wastewater in an Internal Circula- tion (IC) Reactor
}

\author{
Su Caili ${ }^{1}$, Ji Baojie ${ }^{2}$, Wang Qun ${ }^{3}$ and Zhu Lingfeng ${ }^{1, *}$ \\ ${ }^{1}$ College of Environment and Municipal Engineering, North China University of Water Resources and Electric Power, \\ Zhengzhou 450011, China \\ ${ }^{2}$ College of Mechanical \& Electrical Engineering, Henan Agricultural University, Zhengzhou 450002, China \\ ${ }^{3}$ Research Institute of Environmental Science Chemistry and Molecular Engineering, Zhengzhou University, Zhengzhou \\ 450001, China
}

\begin{abstract}
An internal circulation (IC) using hydrogen-producing anaerobic granular sludge as seed sludge and beer wastewater as substrate was employed to evaluate the effect of hydrogen production and the performance of reactor. Running at the temperature of $35 \pm 1{ }^{\circ} \mathrm{C}$, the $\mathrm{pH}$ value of influent controlled is 5.5 and organic loading rate (OLR) from $30 \mathrm{~kg}$ $\mathrm{COD} /(\mathrm{m} 3 \bullet \mathrm{d})$ to $42 \mathrm{~kg} \mathrm{COD} /(\mathrm{m} 3 \bullet \mathrm{d})$, the IC reactor presents a high hydrogen production ability as the hydrogen production rate $(\mathrm{HPR})$ maximized at $6.0-6.83 \mathrm{~m} 3 /(\mathrm{m} 3 \bullet \mathrm{d})$. Hydrogen volume content was estimated to be $42-46 \%$ of the total biogas and the biogas was free of methane throughout the study. COD removal efficiency could reach 20-30\% and the dissolved fermentation products were predominated by ethanol with the concentration of $900-950 \mathrm{mg} / \mathrm{L}$, which accounts for $45 \%$ $56 \%$ of the total liquid products. These values may imply that the IC reactor is a kind of feasible fermentative hydrogen production equipment.
\end{abstract}

Keywords: IC reactor, hydrogen production, Beer wastewater, Ethanol-type fermentation.

\section{INTRODUCTION}

Hydrogen is considered as an important future energy source for it has high energy density, clean and versatile [1]. Among all hydrogen-producing processes, hydrogen production by bio-fermentation is considered as the most promising one for its outstanding features of mild process conditions, low energy consumption and abundant raw materials. It has become an increasingly popular hot spot among researchers around the globe $[2,3]$. The key factors of biological hydrogen production technology for industrial applications are developing efficient bio-hydrogen reaction equipment, improving energy recovery efficiency and reducing production costs. At present researches of hydrogen production by biofermentation mostly concentrate on continuously stirred tank reactor (CSTR) [4-6], Up-flow Anaerobic Sludge Bed (UASB) [7] and expanded granular sludge bed (EGSB) [8]. IC reactor is the third generation of effective anaerobic reactor, which has some outstanding characteristics such as high volume loading rate, less occupied area, strong ability for resisting shock loading and wide application in high concentration organic wastewater treatment $[9,10]$. However, the application of IC reactor in hydrogen production has not been discussed. In this study, IC reactor with hydrogenproducing anaerobic granular sludge as seed sludge is developed for fermentative hydrogen production from beer

*Address correspondence to this author at the No.36 North Ring Road, Zhengzhou, 450011, China; E-mail: Zhulingfeng@ ncwu.edu.cn wastewater. The results will provide technical basis for the engineering application of fermentative hydrogen production.

\section{MATERIAL AND METHODS}

\subsection{Reactor}

This lab-scale IC reactor was made of Plexiglas with a column section of $140 \mathrm{~mm}$ internal diameter, $1500 \mathrm{~mm}$ in length and $1260 \mathrm{~mm}$ in reaction zone height (Fig. 1). The reactor had a working volume of $18.46 \mathrm{~L}$ and the three-phase separator capacity of $6.16 \mathrm{~L}$. The out part of the reactor was covered with a black soft film for dark .The process was operated at $35 \pm 1^{\circ} \mathrm{C}$ by uniformly enwinding heating thread out part of the reactor. A continuous culture was introduced by feeding substrate to the bottom of the reactor with a peristaltic pump. The biogas generated was collected with water seal and measured by wet gas meters (Model LML-1, Changchun Filter Co. Ltd., Changchun, China) which were filled with acidified saturated salt solution in order to prevent the biogas from dissolution.

\subsection{Experimental Wastewater and Seed Sludge}

The experimental wastewater containing a high concentration of organic matter was obtained from China resources Snow breweries (Zhengzhou). Influent COD was about $10000 \mathrm{mg} / \mathrm{L}, \mathrm{pH}$ value varied from 5.0 to 6.0. 


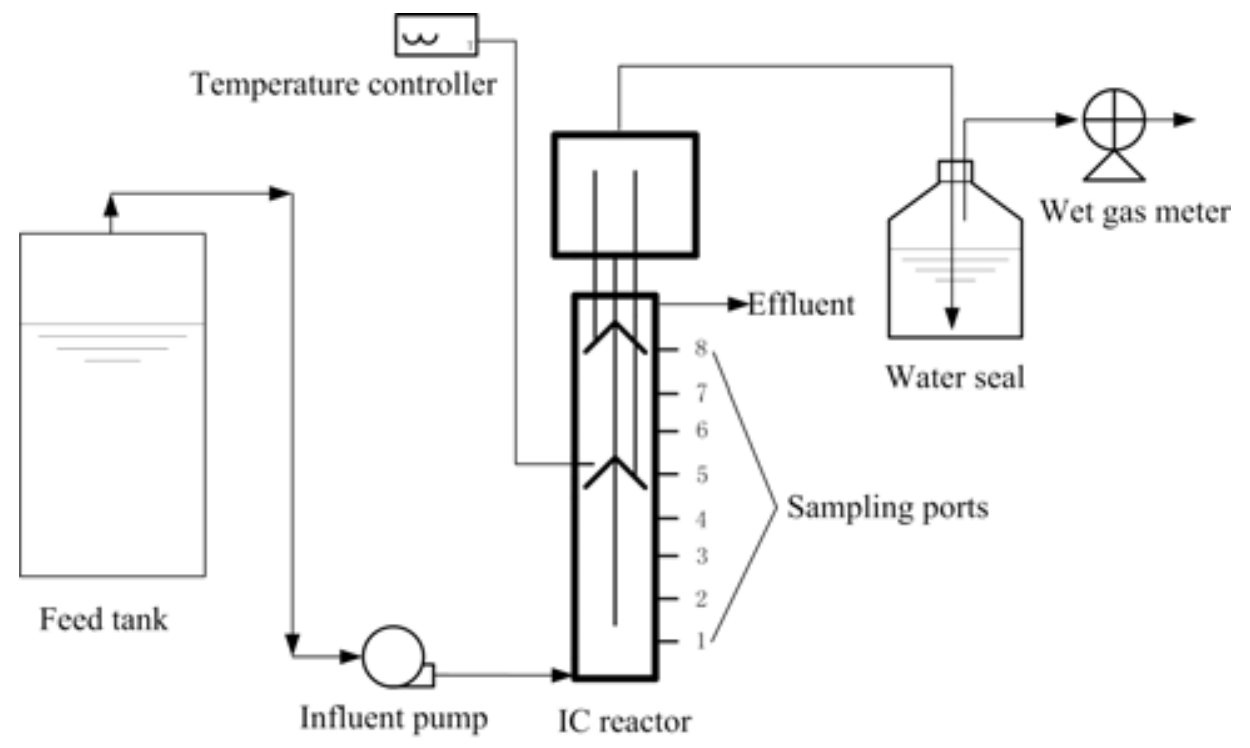

Fig. (1). Schematic diagram of the IC reactor.

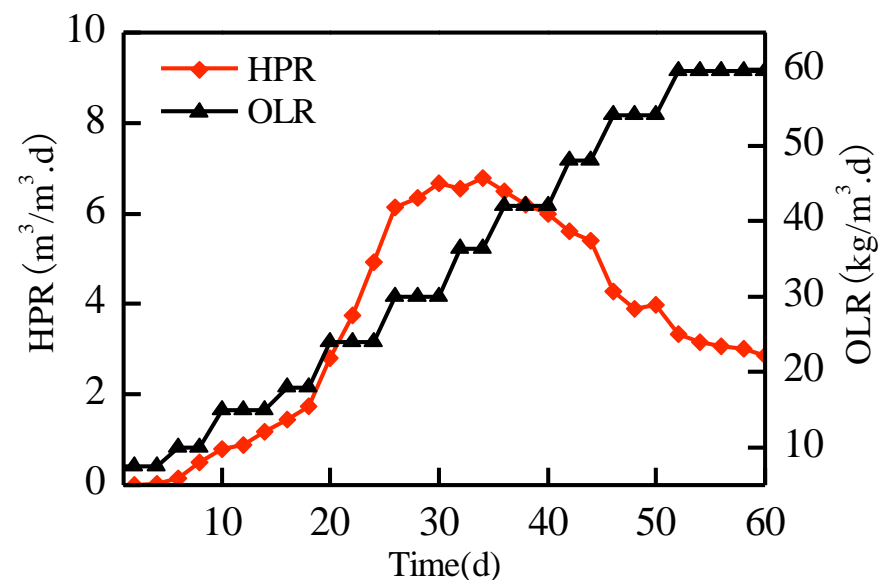

Fig. (2). Hydrogen production rate and OLR variation.

The feed sludge was fresh hydrogen-producing anaerobic granular sludge obtaining from fermentative hydrogenproducing IC reactor, with diameter of 0.5-2.0 $\mathrm{mm}$, volatile suspended solids (VSS) of $10.5 \mathrm{~g} / \mathrm{L}$.

\subsection{Bioreactor Start-up and Operation}

The initial influent was diluted by tap water to control the COD around $2500 \mathrm{mg} / \mathrm{L}$. In the first fifteen days, OLR increased gradually from $7.5 \mathrm{~kg} \mathrm{COD} /\left(\mathrm{m}^{3} \bullet \mathrm{d}\right)$ to $15 \mathrm{~kg}$ $\mathrm{COD} /\left(\mathrm{m}^{3} \cdot \mathrm{d}\right)$ by keeping influent $\mathrm{COD}$ at $2500 \mathrm{mg} / \mathrm{L}$ and reducing the hydraulic retention time(HRT) from $8 \mathrm{~h}$ to $4 \mathrm{~h}$ step by step; In the sixteenth to sixtieth day, OLR increased gradually from $15 \mathrm{~kg} \mathrm{COD} /\left(\mathrm{m}^{3} \cdot \mathrm{d}\right)$ to $60 \mathrm{~kg} \mathrm{COD} /\left(\mathrm{m}^{3} \cdot \mathrm{d}\right)$ by keeping HRT at $4 \mathrm{~h}$ and increasing influent COD from 2500 $\mathrm{mg} / \mathrm{L}$ to $10000 \mathrm{mg} / \mathrm{L}$ little by little.

\subsection{Analytical Methods}

The COD and $\mathrm{pH}$ were measured according to standard methods [11], Hydrogen content in the biogas was deter- mined by gas chromatography (GC, Agilent 4890, American).

Ethanol and volatile fatty acid concentrations (VFA) were assessed using Gas Chromatography (GC-14, Shimadzu, Japan).

\section{RESULTS AND DISCUSSION}

\subsection{Reactor Performance of Hydrogen Production}

The hydrogen production rate (HPR) has generally been considered as an important parameters to evaluate the reactor performance of hydrogen production. Fig. (2) depicts the HPR variations with OLR.

Fig. (2) showed that from the $1^{\text {st }}$ to the $34^{\text {th }}$ day HPR increased as OLR increased, while HPR showed a downward trend as OLR continued to increase after the $34^{\text {th }}$ day. In the start-up stage $\left(1^{\text {st }}\right.$ to the $12^{\text {th }}$ day), OLR was $7.0-15 \mathrm{~kg}$ $\mathrm{COD} /\left(\mathrm{m}^{3} \bullet \mathrm{d}\right)$, the corresponding HPR was less than 1.0 
Table 1. Comparison of HPR from some other studies.

\begin{tabular}{|c|c|c|c|}
\hline Reactor Type & Maximum HPR & Substrate Types & Reference Source \\
\hline \hline CSTR & 4.77 & Glucose & {$[12]$} \\
\hline CSTR & 2.25 & Sucrose & Sucrose \\
\hline UASB & 2.39 & molasses & {$[13]$} \\
\hline EGSB & 7.43 & Beer wastewater & {$[15]$} \\
\hline IC & 6.83 & This study \\
\hline
\end{tabular}

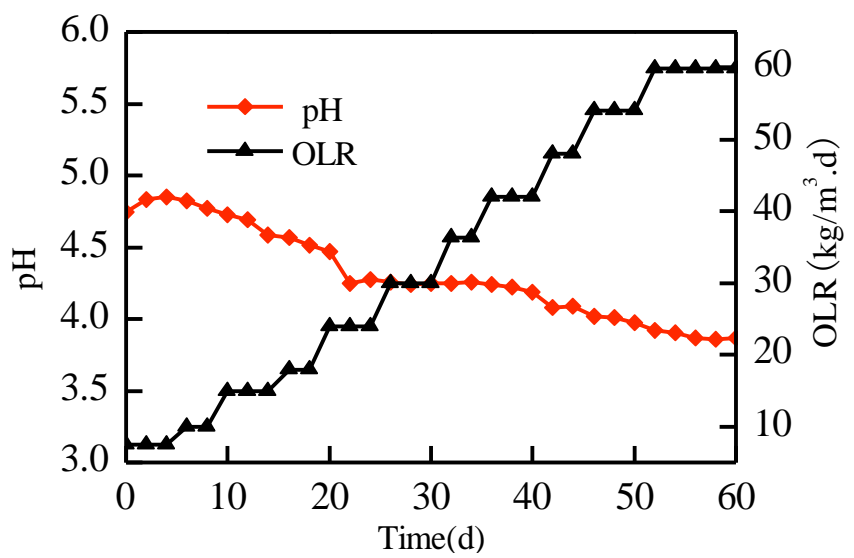

Fig. (3). pH of effluent variations with OLR.

$\mathrm{m}^{3} /\left(\mathrm{m}^{3} \bullet \mathrm{d}\right)$; When OLR increased to $30-42 \mathrm{~kg} \mathrm{COD} /\left(\mathrm{m}^{3} \bullet \mathrm{d}\right)$, the corresponding HPR was about $6.0-6.83 \mathrm{~m}^{3} /\left(\mathrm{m}^{3} \bullet \mathrm{d}\right)$; when OLR continued to increase to $48-60 \mathrm{~kg} \mathrm{COD} /\left(\mathrm{m}^{3} \bullet \mathrm{d}\right)$, the corresponding HPR was about $2.8-4.2 \mathrm{~m}^{3} /\left(\mathrm{m}^{3} \bullet \mathrm{d}\right)$. The maximum HPR of $6.83 \mathrm{~m}^{3} /\left(\mathrm{m}^{3} \bullet \mathrm{d}\right)$ was observed with an OLR of $36 \mathrm{~kg} \mathrm{COD} /\left(\mathrm{m}^{3} \cdot \mathrm{d}\right)$. During the gas production process of the $1^{\text {st }}$ to the $24^{\text {th }}$ day, hydrogen volume content increased over time and was estimated to be $5-35 \%$ of the total biogas. After $24^{\text {th }}$ day, hydrogen volume content kept the level of $42 \%-46$ $\%$. According to the analysis, OLR has a significant influence on the effect of hydrogen production of IC reactor. In order to obtain a preferable fermentative hydrogenproducing effect of beer wastewater, the OLR of IC reactor should not exceed $45 \mathrm{~kg} \mathrm{COD} /\left(\mathrm{m}^{3} \bullet \mathrm{d}\right)$.

The comparison of HPR from continuous flow hydrogen production reported in the previous researches were summarized in Table 1. According to Table 1, IC reaction in this research have a relative high level of HPR, which proved that IC reactor can obtain a preferable hydrogen-producing efficiency under high OLR and have pretty good development prospects as biological hydrogen-producing process.

\subsection{Variations in $\mathbf{P H}$}

Environmental $\mathrm{pH}$ was proved to play an important role in fermentative hydrogen production performance. Acidproducing fermentation bacteria had great $\mathrm{pH}$ adaptability.
The optimal $\mathrm{pH}$ range for most bacteria was 5.0 8.5, some acid-producing fermentation bacteria can exist under $\mathrm{pH}$ of 4.0. $\mathrm{pH}$ has great effect on the bio-hydrogen production process, which would not only influence certain enzyme activity and the growth rate of bacteria but also change the status and amount of dominant bacterial populations in reactor and would further change the fermentation pathway and affect the hydrogen-producing effect of acid- producing fermentation bacteria populations. Ren [16] pointed that the optimal $\mathrm{pH}$ range of hydrogen production from ethanol type fermentation was 4.2 4.5, which used molasses wastewater as influent. Lay [17] pointed that the optimal $\mathrm{pH}$ range of hydrogen production from butyric acid type fermentation was 6.7. In this study, $\mathrm{pH}$ of influent was controlled around 5.5. Fig. (3) depicts $\mathrm{pH}$ of effluent variations with OLR.

Fig. (3) showed that $\mathrm{pH}$ of effluent presented a downward trend as OLR increased. When influent OLR was less than $42 \mathrm{~kg} \mathrm{COD} /\left(\mathrm{m}^{3} \bullet \mathrm{d}\right), \mathrm{pH}$ of effluent maintained between 4.2-4.8. While influent OLR increased to more than $54 \mathrm{~kg}$ $\mathrm{COD} /\left(\mathrm{m}^{3} \bullet \mathrm{d}\right), \mathrm{pH}$ value of effluent dropped to below 4.0. According to the variation of HPR, it maintained at a relative high level when OLR between $30-42 \mathrm{~kg} \mathrm{COD} /\left(\mathrm{m}^{3} \bullet \mathrm{d}\right)$, meanwhile, $\mathrm{pH}$ value of effluent reached 4.2-4.3. The result was in accordance with the study of Ren [16]. During the whole process, no methane gas was detected, which indicated that low $\mathrm{pH}$ effectively inhibited methanogenesis. 


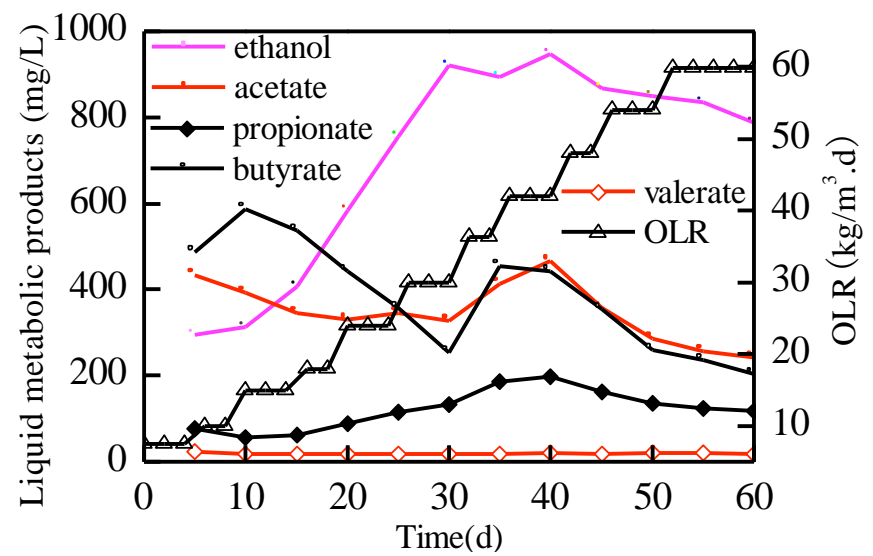

Fig. (4). Liquid metabolic products and OLR variation in the IC reactor.

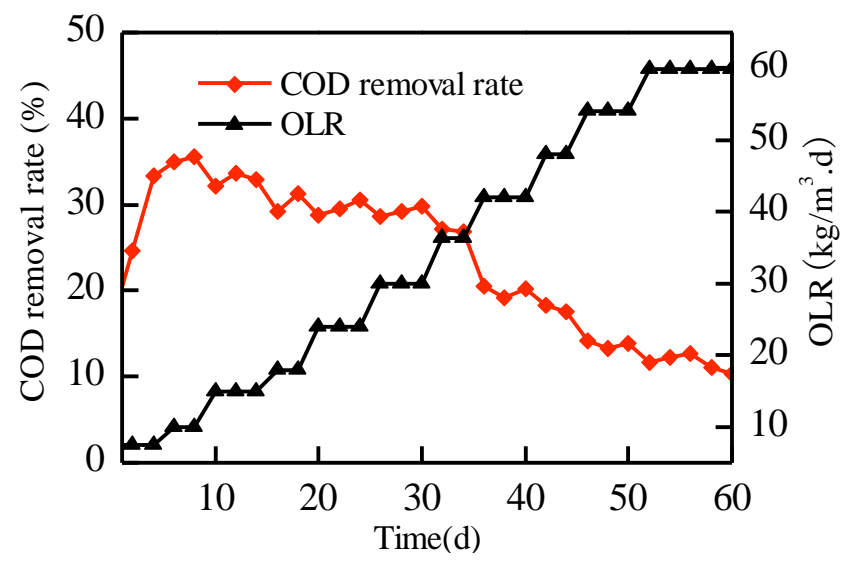

Fig. (5). COD removal rate and OLR variation in start-up stage.

\subsection{Composition of Liquid end Production}

Anaerobic fermentative hydrogen production is divided into 3 types: butyric acid type fermentation, propionic acid type fermentation and ethanol type fermentation. In many papers, butyrate-type fermentation has been depicted as the most popular pathway for fermentative hydrogen production $[5,18]$. In this process, Liquid metabolic products and OLR variation in the IC reactor were shown in Fig. (4).

According to Fig. (4), in the first 15 days from start-up, butyric acid accounted for the largest amount of liquid end production, followed by acetic acid and ethanol; as the OLR increased, the ethanol concentration in liquid end production kept rising and reached $756 \mathrm{mg} / \mathrm{L}$ at day 25, which accounted for $47.45 \%$ of total VFAs. This indicated that bacteria producing hydrogen, acid, and ethanol had the dominant position in the reactor. When OLR continued to increase to $60 \mathrm{~kg} \mathrm{COD} /\left(\mathrm{m}^{3} \cdot \mathrm{d}\right)$, ethanol was always the main product of fermentative production, which indicated that the main type of reactor was ethanol type fermentation. When OLR was $30-42 \mathrm{~kg} \mathrm{COD} /\left(\mathrm{m}^{3} \bullet \mathrm{d}\right)$, ethanol concentration reached maximum of $900-950 \mathrm{mg} / \mathrm{L}$ accounting for $45 \%-56 \%$ of total VFAs. Combining this with HPR variation (Fig. 2), it showed that variation of ethanol concentration and HPR were positively correlated.

\subsection{COD Removal Rate}

In this process, influent COD was gradually increased from $2500 \mathrm{mg} / \mathrm{L}$ to $10000 \mathrm{mg} / \mathrm{L}$ and COD removal rate is shown in Fig. (5). According to Fig. (5), when influent OLR was gradually increased from $7.5 \mathrm{~kg} \mathrm{COD} /\left(\mathrm{m}^{3} \bullet \mathrm{d}\right)$ to $30 \mathrm{~kg}$ $\mathrm{COD} /\left(\mathrm{m}^{3} \bullet \mathrm{d}\right), \mathrm{COD}$ removal rate maintained at $30 \% \sim 35 \%$; when OLR was $30 \sim 42 \mathrm{~kg} \mathrm{COD} /\left(\mathrm{m}^{3} \bullet \mathrm{d}\right)$, COD removal rate maintained at 20\% 30\%. When influent COD was increased to $8000 \sim 10000 \mathrm{mg} / \mathrm{L}$, OLR reached $48-60 \mathrm{~kg} \mathrm{COD} /\left(\mathrm{m}^{3} \bullet \mathrm{d}\right)$, COD removal rate gradually decreased from $20 \%$ to $10.35 \%$. The result indicated that COD removal rate could reach $20 \%$ 30\% under the condition of high hydrogen-producing effect in IC reactor.

\section{CONCLUSION}

Using fermentative hydrogen production with beer wastewater as substrate showed that when the condition of OLR was at $30-42 \mathrm{~kg} \mathrm{COD} /\left(\mathrm{m}^{3} \bullet \mathrm{d}\right)$, HPR was about 7.0-7.8 $\mathrm{m}^{3} /\left(\mathrm{m}^{3} \bullet \mathrm{d}\right)$ and hydrogen content was $42-46 \%$; COD removal rate was up to $20-30 \%$, maximum HPR was $7.83 \mathrm{~m}^{3} /\left(\mathrm{m}^{3} \cdot \mathrm{d}\right)$ with corresponding OLR of $36 \mathrm{~kg} \mathrm{COD} /\left(\mathrm{m}^{3} \bullet \mathrm{d}\right)$. During the whole operation process, the main fermentation type in IC reactor was ethanol type fermentation. At the stage of high 
HPR, ethanol was the main products of liquid end production with the concentration of $900-950 \mathrm{mg} / \mathrm{L}$, accounting for $45 \%-56 \%$ of total VFAs.

\section{CONFLICT OF INTEREST}

The authors confirm that this article content has no conflict of interest.

\section{ACKNOWLEDGEMENTS}

This study was supported by the scientific and technological project of the Education Department of Henan Province (No.12A610008).

\section{REFERENCES}

[1] Hoffmann, P. Tomorrow's Energy-Hydrogen, Fuel Cells and the Prospects for a Cleaner Planet. MIT Press, Cambridge, MA, 2001.

[2] Mohan, S.V. Fermentative hydrogen production with simultaneous wastewater treatment: influence of pretreatment and system operating conditions. J. Sci. Indust. Res., 2008, 67, 950-961.

[3] Hallenbeck, P.C.; Ghosh, D. Advances in fermentative biohydrogen production: the way forward. Trends Biotechnol., 2009, 27, 287-297.

[4] Kim, S.H.; Han, S.K.; Shin, H.S. Performance comparison of a continuous-flow stirred-tank reactor and an anaerobic sequencing batch reactor for fermentative hydrogen production depending on substrate concentration. Water Sci. Technol., 2005, 52, 23-29.

[5] Ren, N.Q.; Chua, H.; Chan, S.Y.; Tsang, Y.F.; Wang, Y.J.; Sin, N. Assessing optimal fermentation type for bio-hydrogen production in continuous acidogenic reactors. Bioresource Technol., 2007, 98, 1774-80.

[6] Lin, C.Y.; Chang, R.C. Fermentative hydrogen production at ambient temperature. Int. J. Hydro. Energy, 2004, 29, 715-720.
[7] Spagni, A.; Casu, S.; Farina, R. Effect of the organic loading rate on biogas composition in continuous fermentative hydrogen production. J. Environ. Sci. Health A Tox Hazard Subst. Environ Eng., 2010, 45, 1475-1481.

[8] Guo, W.Q.; Ren, N.Q.; Wang, X.J.; Xiang, W.S.; Meng, Z.H.; Ding, J.; Qu, Y.Y.; Zhang, L.S. Biohydrogen production from ethanol-type fermentation of molasses in an expanded granular sludge bed (EGSB) reactor. Int. J. Hydro. Energy, 2008, 33, 4981-4988.

[9] Pereboom, J.H.F.; ereijken, T.L.F.M.V. Methanogenic granule development in full scale internal circulation reactors. Water Sci. Technol., 1994, 30, 9-21.

[10] Habets, L.H.A.; Engelaar, A.J.H.H.; Groeneveld N. Anaerobic treatment of inuline effluent in and internal circulation reactor. Water Sci. Technol., 1997, 35, 189-197.

[11] American Public Health Association (APHA). Standards methods for the examination of water and wastewater, 1998.

[12] Mizuno, O.; Dinsdale, R.; Hawkes, F.R.; Hawkes, D.L.; Noike, T. Enhencement of hydrogen production from glucose by nitrogen gas sparging. Bioresource Technol., 2000, 73, 59-65.

[13] Sung, S.; Raskin, L.; Duangmanee, T.; Padmasiri, S.; Simmons, J.J. Hydrogen production by anaerobic microbial communities exposed to repeated heat treatments. In: Proceedings of the 2002 U.S.DOE, 2002.

[14] Lin, C.Y.; Lay, C.H. Carbon/nitrogen-ratio efect on fermentative hydrogen production by mixed microflora. Int. J. Hydro. Energy, 2004, 29, 41-45.

[15] Guo, W.Q.; Ren, N.Q.; Qu, Y.; Wang, X.; Xiang, W.S. Continuous operation and hydrogen production characteristics of a novel hydrogen production reactor. Acta Energlae Solaris Sinica, 2009, 30, 397-401.

[16] Ren, N.Q.; Wang, B.Z.; Huang, J.C. Ethanol-type fermentation from Carbohydrate in High Rate Acidogenic Reactor. Biotechnol. Bioeng., 1997, 54, 428-433.

[17] Lin, C.Y.; Jo, C.H. Hydrogen production from sucrose using an aaerobic sequencing batch reactor process. J. Chem. Technol. Biotechnol., 2003, 7, 678-684.

[18] Li, Y.F.; Ren, N.Q.; Chen, Y.; Zheng, G.X. Ecological mechanism of fermentative hydrogen production by bacteria. Int. J. Hydro. Energy, 2007, 32, 755-760.

(C) Caili et al.; Licensee Bentham Open.

This is an open access article licensed under the terms of the Creative Commons Attribution Non-Commercial License (http://creativecommons.org/licenses/by$\mathrm{nc} / 3.0 /$ ) which permits unrestricted, non-commercial use, distribution and reproduction in any medium, provided the work is properly cited. 